\title{
NOTES
}

\section{TWO PREVIOUSLY UNDOCUMENTED REVIEWS OF LEAVES OF GRASS}

\author{
1. Leaves of Grass (1856): "Universally admired by men whose authority is \\ unquestionable"
}

Pasted within one of Walt Whitman's scrapbooks, now preserved in the Charles E. Feinberg Collection at the Library of Congress, are two 1856 reviews of Leaves of Grass published within months of one another in the New York Daily News. One of those reviews - a short, but favorable notice of the second edition of Leaves of Grass, reprinted below and soon available on the Walt Whitman Archive - has until now remained undocumented.

In February of 1856 the Daily News dubbed the first edition of Leaves of Grass "the strangest, most extraordinary production" ever reviewed in its pages. The Daily News repeats this sentiment in the November 28, 1856, article transcribed below, characterizing Whitman's work as "universally admired by men whose authority is unquestionable." This lofty appraisal of the second edition is no doubt influenced by two distinctive characteristics of the 1856 Leaves of Grass itself: Whitman's controversial decision to gold stamp Ralph Waldo Emerson's personal praise of the poet in 1855 ("I greet you at the beginning of a great career") on the spine of the volume, and the lengthy appendix "Leaves-Droppings," which reprinted, among other items, Emerson's letter in full along with Whitman's response to his "Master." Though not "universally admired," the design of the 1856 Leaves of Grass suggested that at least one man of "unquestionable" authority stood behind Whitman's poetry.

Many reviewers of this edition were incensed by Whitman's unauthorized use of Emerson's endorsement on the cover, but this Daily News review is a reminder that some found the material presentation of the 1856 edition refreshing, shameless blurb and all. Much like the Brooklyn Daily Times, which lauded the improved typography of Whitman's second edition, the Daily News describes the compact, cramped, yet "neatly printed" pages of the 1856 Leaves of Grass as a "decided improvement" on the 1855 edition.

Whitman's personal copy of the review was clipped out of the newspaper mid-quotation; the transcription below reprints, in brackets, the missing passage as it appears in the 1856 Leaves of Grass. 


\section{OUR BOOK TABLE}

Leaves of Grass. Brooklyn, New York, 1856. For sale by Fowler \& Wells, No. 308 Broadway.

A new edition of Walt Whitman's wonderful poems.

Leaves of Grass was first published something more than a year ago. It then appeared in a quarto form of 89 pages, and, as we understand, was set up and printed by the author himself. The present edition is a decided improvement on the first; it contains 384 pages, 18mo., and being neatly printed is much more desirable than the quarto.

We have heretofore reviewed Walter Whitman's poems, and spoken of them at considerable length, and spoken very highly of them, too. It is, of course, unnecessary to repeat what we have previously said, or even to enter largely into a discussion of the eccentricities of the author, or the peculiarities and the beauties of his poems. It will be sufficient to say that they have been almost universally admired by men whose authority is unquestionable, and with scarcely an exception, have been highly praised by the press of both this country and of England.

Some of these "leaves-droppings" will be found at the end of the book, together with the correspondence between Ralph Waldo Emerson and the author. The beautiful testimonial from Mr. Emerson has been the means of gaining for Walt Whitman an increased number of admirers.

In Walt Whitman's letter to Mr. Emerson, he writes in precisely the same style as he does in his poems. From that letter we take the following extract. It presents an idea of his manner of writing, and truthfully describes a class of persons who are exactly opposite to Walt Whitman. Here it is, and with it we close our notice:

Up to the present, as helps best, the people, like a lot of large boys, have no determined tastes, are quite unaware of the grandeur of themselves, and of their destiny, and of their immense strides-accept with voracity whatever is presented them in novels, histories, newspapers, poems, schools, lectures, everything. Pretty soon, through these and other means, their development makes the fiber that is capable of itself, and will assume determined tastes. The young men will be clear what they want, and will have it. They will follow none except him whose spirit leads them in the like spirit with themselves. Any such man will be welcome as the flowers of May. Others will be put out without ceremony. How much is there anyhow, to the young men of these States, in a parcel of helpless dandies, who can neither fight, work, shoot, ride, run, command-some of them devout, [some quite insane, some castrated-all second-hand, or third, fourth, or fifth hand-waited upon by waiters, putting not this land first, but always other lands first, talking of art, doing the most ridiculous things for fear of being called ridiculous, smirking and skipping along, continually taking off their hats - no one behaving, dressing, writing, talking, loving, out of any natural and manly tastes of his own, but each one looking cautiously to see how the rest behave, dress, write, talk, love-pressing the noses of 
dead books upon themselves and upon their country-favoring no poets, philosophs, literats here, but dog-like danglers at the heels of the poets, philosophs, literats, of enemies' lands-favoring mental expressions, models of gentlemen and ladies, social habitudes in These States, to grow up in sneaking defiance of the popular substratums of The States?]

The New York Daily News was an early champion of Leaves of Grass, but, when the third edition appeared in 1860, the paper's proslavery sympathies were out of step with Thayer \& Eldridge, Whitman's new abolitionist publishers. An article on the September 1860 New York Trade Sale of Books demonstrates how the radical politics of Whitman's Boston publishers had tainted Leaves of Grass for the Daily News. A list of Thayer \& Eldridge's publications-“Life of the Savior . . . the Life of Lincoln, Capt. John Brown, Wm. H. Seward, Echoes of Harper's Ferry, Sumner's Speech"_-concludes by mentioning "Walt Whitman's Leaves of Grass, and other Black Republican documents." Just exactly how Leaves of Grass functioned as a "Black Republican" document is unclear, but Whitman's association with an active abolitionist publishing house was possibly enough incentive for the Daily Nervs to ignore the poet's newest volume except for this brief mention.

\section{Leaves of Grass (1860): "Unprecedented insult upon a refined society"}

The third edition of Leaves of Grass was similarly ignored in the South. Though Whitman's persona was still notorious in that region during 1860, there are almost no documented, full-length reviews of the Thayer \& Eldridge volume published in southern periodicals. ${ }^{3}$ Until now, the only such review was John R. Thompson's anonymous notice in Georgia's Southern Field and Fireside. However, this recently discovered review transcribed below (and soon available on the Walt Whitman Archive) from Centre College Magazine, a literary monthly founded in 1859 and published out of Kentucky by the Presbyterian-affiliated Centre College, adds to our growing understanding of Whitman's reception in the South as the nation approached civil war.

The magazine's anonymous reviewer is willing to grant that Whitman and his poetry are "original" in "form, style and binding, as well as reading matter." Even further, by the periodical's own definition, Leaves of Grass, a "prodigy of oddness and singularity," evinces Whitman's "genius." But Centre College Magazine is far less forgiving when it comes to Whitman's "base and abject soul." Like many contemporary reviews, the moralizing tone of this piece shies away from reprinting any passages that might fully illustrate Whitman's "depravity and grossness." Instead, the review allows only "fair examples of all that which is not too gross and obscene" in Leaves of Grass "to stain this page." Ironically, the excerpt from the poem "Walt Whitman" that appears below this editorial disclaimer inadvertently heightens the sexual innuendo (and staining potential) of Whitman's verse by capitalizing the last three words of the line- "Your LOVER Comes"-while in Leaves of Grass only "Your Lover" is emphasized typographically. Apparently, Whitman's words three lines later in the 1860 edition- "Thruster holding me tight, and that 
I hold tight! / We hurt each other as the bridegroom and the bride hurt each other"-were sufficiently "obscene" to be censored.

Perhaps the only distinctly southern quality of the Centre College Magazine review is its eager appropriation of a passage from chapter 16 of William Gilmore Simms's novel Beauchampe: or The Kentucky Tragedy: A Tale of Passion (1842), a work based on the sensational murder of Solomon P. Sharp by Jereboam O. Beauchamp in 1825 . The unattributed lines are taken from a scene in the novel describing a rally in Bowling Green, Kentucky, where an "unctuous" politician - who "rains precious drops ... which might be eloquence, if it were not balderdash!"- delivers a theatrical speech to his constituency. The protagonist, Beauchampe, eventually sees past the politician's empty rhetoric, but not before initially being misled by the speaker's veneer of power and eloquence: "'Who is this man!' quoth our young hero, Beauchampe, as he listened to the muddy torrent, which, like some turbid river, having overflowed its banks, comes down, rending and raging, a thick flood of slime and foam, bringing along with it the refuse of nauseous places, and low flats, and swampy bottoms, and offal stalls! The youth was bewildered. The eloquent man was so sure of his ground and auditors - seemed so confident in his strength - so little like a doubting giant - that it was long before Beauchampe could discover that he was a mere wind-bag, a bloated vessel of impure air that, becoming fixed air through a natural process, at length explodes and breaks forth with a violence duly proportioned to its noisomeness." Whitman's poetry, Centre College Magazine warns its readers, is equally full of "balderdash" and must be approached critically in order to expose Whitman for what he is, "a bloated vessel of impure air." The review is transcribed below in full:

\section{Leaves of Grass. ${ }^{5}$}

At length is anxious expectation relieved, and the public curiosity gratified.

Walt. Whitman's "Leaves of Grass," has made its appearance, revised and enlarged in this - the Third Edition. The very title is the synonym for excentricity [sic]. In form, style and binding, as well as reading matter, it is a prodigy of oddness and singularity.

Emphatically can the author claim for himself, with all justice, the merit of originality. That the production evinces genius, is unquestionable-if you define genius to be the great ruling faculty, the "Pharos of the mind," that which invents and creates of its own innate power, and clothes its creatures in that mystic garb, which only genius can command. In fact, to say that the poem has originality, implies the operation of genius. For what can be original that is not an offering of genius? This is certainly a merit, and it redeems somewhat the character of the book.

We have read somewhere, a very apt comparison of a "balderdash" politician's speech to "some turbid river, which, having overflowed its banks, comes down, rending and raging a thick flood of slime and foam-bringing along with it the refuse of nauseous places, and low flats and swampy bottoms. ["] This comparison will admirably apply in the present instance.

WaLt Whitman's poem is but an agglomeration of rude, barbarous, gro- 
tesque - thoughts, expressed in quaint, whimsical, abnormal words, often breathing sentiments the very lowest - full of the most abandoned depravity. His is not a soul

"To gentle harmonies attuned."

He is, as he himself expresses it—"free, fresh, savage,"- "one of the roughs," and as we express it, a stranger to refinement, a slave to the brute passion.

He seems utterly devoid of all the "nobler emotion."-Love he does not know. Beauty in woman he looks upon only as the object of passion.

His base and abject soul can not properly appreciate the fairest and best of all God's works, whose mission is tenderness and love; the ministers of joy in the hour of sorrow; of condolence in the hour of desolation; of peace in trouble, trial and affliction. This of itself, should damn him in the public mind, and strike his bold, insolent and unblushing head into the dust of public scorn and loathing. Unprecedented insult upon a refined society! He dares raise his repulsive head and hurl indignity and affront in the face of an enlightened reading public - the coarse, unrefined expression of his own depravity and grossness.

Reader, examine his volume, and you will ascertain that we do not speak extravagantly. No language is too strong to express his dissoluteness and laxity of morals. And yet, WALt Whitman has some redeeming qualities. We speak now of mental attributes, not of moral. We think no one after a perusal of "LEAVES OF GRASS," would dare admit that its author was possessed of moral characteristics.- Surely we will not hazard such a statement. We have said above, that he has genius; that this work was a production of genius. This will be readily admitted.

But surely a wanton, unchaste Muse was consulted; and wanton, unchaste poetry was produced. Yet there are interspersed in the poem, thoughts of wild, uncouth beauty, which can not fail to charm the reader-such gems, sparkling in the "slime and foam" drifting on this "turbid river's" bosom. But that the reader may be better able to judge of the merits of the book, we quote some lines-fair examples of all that which is not too gross and obscene to stain this page.

"Smile, O voluptuous cool-breathed Earth!

Earth of the slumbering and liquid trees!

Earth of departed sunset! Earth of the mountains misty topt!

Earth of the vitreous pour of the full moon, just tinged with blue!

Earth of shine and dark, moulding the tide of the river!

Earth of the limpid gray of clouds, brighter and clearer for my sake!

Far-swooping, elbowed Earth! Rich, apple-blossomed Earth!

Smile for Your Lover Comes!”

To comment is useless. You readily perceive the remarkable oddness, the peculiar style, and, we may add, beauty of the lines.

The ensemble may be easily imagined from the character of this part. Again:-

"I celebrate myself,

And what I assume, you shall assume;

For every atom belonging to me, as good belongs to you. 
I loafe and invite my soul,

I lean and loafe at my ease, observing a spear of summer grass.

Houses and rooms are full of perfumes - the shelves are crowded with perfumes.

I breath the fragrance myself, and know it and like it;

The distillation would intoxicate me also, but I shall not let it."

The reader would be favorably impressed rather than otherwise with the above extracts. They are such as would excite the curiosity and create a desire to read the remainder of a book-these parts of which are so strikingly peculiar. But these are but gems we have caught from the nauseous mass; the lilies plucked from the garden of rank weeds. Reader we have done; examine "LEAVES OF GRASs" for yourself, and if you think we have done WALT WHITMAN injustice, surely his language is capable of two constructions.

We close with his own words:

"Dear friends-whoever you are-here-take this kiss.

I give it especially to you-do not forget me;

I feel like one who has done his work. I progress on,

The unknown sphere, more real than I dreamed; more direct, darts awakening rays about me.

So Long!

Remember my words-I love you-I depart from materials;

I am as one disembodied-triumphant-dead!"

University of Iowa

ERIC CONRAD

\section{NOTES}

1 “Our Book Table," New York Daily News (November 28, 1856).

2 “The Trade Sale," New York Daily News (August 17, 1860), 4.

3 For examples of how Whitman's poetry and persona circulated in the South at this time, see Eric Conrad, "Whitman and the Proslavery Press: Newly Recovered 1860 Reviews.” Walt Whitman Quarterly Review 27 (Spring 2010), 227-233.

4 See William Gilmore Simms, Beauchampe: or The Kentucky Tragedy: A Tale of Passion (New York: Redfield, 1856), 174-175.

5 “Leaves of Grass," Centre College Magazine (September 1, 1860), 13-16.

6 An allusion to an early blank verse poem by Daniel Webster published in the Dartmouth Gazette; the line is taken from a passage describing the creation of earth and the qualities of prelapsarian man (quoted in Life of Daniel Webster, Statesman and Patriot [Boston: Lee and Shepard, 1868], 110): 
When that grand period in the eternal mind, Long predetermined, had arrived, behold The universe, this most stupendous mass Of things, to instant being rose. This globe, For light and heat dependent on the sun,

By power supreme was then ordained to roll And on its surface bear immortal MAN, Complete in bliss, the image of his GoD. His soul, to gentle harmonies attuned, Th' ungovern'd rage of boisterous passion knew not. 